\title{
Framing Advokasi Perkuliahan Tatap Muka di Masa Normal Baru dalam Pemberitaan Kedaulatan Rakyat
}

\author{
Widowati Maisarah \\ Fakultas Dakwah dan Komunikasi, UIN Sunan Kalijaga Yogyakarta \\ widowati.maisarah@gmail.com
}

\begin{abstract}
The Covid-19 pandemic has affected all sectors of life, including the education sector. In order to surppress the spread of the virus, the educational process is carried out by means of online learning, including lectures at universities. Apart from facing many technical barriers, online lectures have an impact on learning methods as well as other broader issues. Yogyakarta relies on regional income from the education sector, particularly on the expenditure of outer regional students. The dilemma between the urgency of re-implementing offline lectures to support economic recovery or prioritizing public health has become an issue that has surfaced in local media coverage. This article explains how the largest local newspaper in Yogyakarta, Kedaulatan Rakyat, framed online lectures during the Covid-19 pandemic in its reporting. Research results show that Kedaulatan Rakyat constructed the news framing of online learning as one of the causes of the regional economic stagnation. Furthermore, the coverage of Kedaulatan Rakyat contains an advocacy narrative which persuades campuses in Yogyakarta to immediately reopen offline learning as a solution to the regional economic stagnation.
\end{abstract}

Keywords: advocacy news framing; covid-19 coverage; new normal coverage; news framing; online learning policy

\begin{abstract}
Abstrak
Pandemi Covid-19 menimbulkan efek di semua sektor kehidupan, tidak terkecuali sektor pendidikan. Demi menekan penularan virus Corona baru, proses pendidikan pun dilakukan dengan cara pembelajaran daring, termasuk perkuliahan di Perguruan Tinggi. Selain mengalami banyak hambatan teknis, perkuliahan daring berdampak pada metode pembelajaran dan bahkan dampak lain yang lebih luas. Seperti apa yang terjadi di Yogyakarta yang mengandalkan pergerakan ekonomi daerah dari sektor pendidikan tinggi khususnya belanja mahasiswa pendatang. Dilema antara urgensi penerapan kembali perkuliahan luring untuk mendukung pemulihan ekonomi atau pengutamaan kesehatan masyarakat menjadi isu yang mengemuka di dalam pemberitaan media lokal. Artikel ini memaparkan bagaimana koran lokal terbesar di Yogyakarta, Kedaulatan Rakyat, membingkai perkuliahan daring di masa pandemi Covid-19 dalam pemberitaannya. Kedaulatan Rakyat membangun framing perkuliahan daring sebagai salah satu penyebab perlambatan ekonomi daerah. Pemberitaan koran tersebut memuat narasi yang advokatif supaya kampus-kampus di Yogyakarta segera membuka kembali perkuliahan tatap muka sebagai solusi atas stagnasi ekonomi daerah.
\end{abstract}

Kata Kunci: framing advokasi; framing berita; kebijakan pembelajaran online; pemberitaan covid-19; pemberitaan normal baru

\section{PENDAHULUAN}

Pandemi Covid-19 memengaruhi banyak sektor kehidupan. Dampaknya sangat signifikan terhadap kesehatan, ekonomi, sosial dan pendidikan. Sifat virus Covid-19 yang mudah menular membuat pemerintah negara-negara di seluruh dunia menerapkan kebijakan pelaksanaan protokol kesehatan seperti penggunaan masker, jaga jarak, rajin cuci tangan dan melarang

Korespondensi: Widowati Maisarah, S.IP., M.A., Fakultas Dakwah dan Komunikasi UIN Sunan Kalijaga Yogyakarta, Jl. Laksda Adisucipto, Papringan, Caturtunggal, Kec. Depok, Kabupaten Sleman, Daerah Istimewa Yogyakarta 55281, Email: widowati.maisarah@gmail.com

Menyerahkan: Desember 2020, Diterima: Januari 2021, Terbit: Januari 2021

ISSN: 2549-0559 (cetak), ISSN: 2549-1946 (online), Website: http://jurnal.unpad.ac.id/kajian-jurnalisme 
adanya kerumunan orang. Penerapan protokol kesehatan ini jelas sangat memengaruhi sektor pendidikan, termasuk pendidikan tinggi.

Kampus-kampus di hampir seluruh wilayah di Indonesia ditutup. Perkuliahan tatap muka diubah menjadi daring dan pelayanan di kampus dibatasi waktunya untuk mengurangi pegawai dan dosen yang bekerja di kantor. Pandemi telah memaksa hampir seluruh kegiatan kampus dilakukan secara daring. Mulai dari kuliah daring, ujian daring, bimbingan skripsi daring sampai wisuda pun dilakukan secara daring.

Perkuliahan daring selama pandemi Covid-19 berimplikasi luas terhadap sektor pendidikan tinggi. Yogyakarta sebagai kota yang dijuluki dengan kota pelajar tentu saja terdampak pula oleh pelaksanaan perkuliahan daring yang dilakukan oleh kampus-kampus yang berada di dalamnya. Sesuai data di dalam Pangkalan Data Pendidikan Tinggi Kementerian Pendidikan Tinggi, terdapat 136 unit perguruan tinggi di Yogyakarta yang tersebar di 5 kabupaten/kota dan memiliki beberapa kategori yaitu akademi, politeknik, sekolah tinggi, institut, dan universitas. Dari keberadaan kampus-kampus tersebut, Daerah Istimewa Yogyakarta mendapat pendapatan daerah sejumlah 1,2 triliun per tahun dari kebutuhan primer mahasiswa (Heru, 2008). Kontribusi ini melebihi pendapatan asli daerah yang hanya 485 miliar rupiah per tahun. Pemasukan daerah secara tidak langsung diperoleh dari tingginya jumlah mahasiswa yang berkuliah dan tinggal di Yogyakarta. Apabila perkuliahan dilakukan secara daring, otomatis jumlah mahasiswa yang tinggal di Yogyakarta mengalami penurunan drastis.

Perkuliahan daring juga memukul dunia usaha kecil dan menengah di Yogyakarta. Banyak usaha kecil dan menengah yang benar-benar menyasar mahasiswa sebagai target pasarnya. Bisnis warung makan, kedai kopi, laundry, fotokopi, indekos, bahkan ojek daring pun mengalami dampak buruk tersebut. Secara tidak langsung, sistem kuliah daring yang dilakukan untuk mencegah penularan virus berdampak negatif terhadap perekonomian lokal di Yogyakarta. Oleh karena itu, pemerintah pusat maupun daerah mencoba mengeluarkan kebijakan-kebijakan yang segera dapat mengantisipasi melambatnya perekonomian melalui kebijakan normal baru (new normal).

Pemerintah Indonesia menerapkan normal baru setelah melakukan karantina wilayah di beberapa kota besar sejak Maret 2020. Normal baru diterapkan sejak bulan Juli 2020 dengan pelonggaran aktivitas masyarakat di semua lini. Kebijakan normal baru diharapkan mampu menghidupkan kembali perekonomian. Tranportasi umum seperti kereta api dan pesawat kembali dibuka meski ada pembatasan jumlah penumpang dan rute, tempat-tempat pariwisata dibuka lagi, kantor-kantor diperbolehkan untuk kembali menerapkan WFO (work from office) dengan melaksanakan protokol kesehatan.

Daerah Istimewa Yogyakarta (DIY) juga memulai normal baru pada bulan Juli 2020. Sektor pariwisata sudah dibuka kembali dan pusat-pusat perdagangan seperti Malioboro juga telah dibuka penuh. Namun sektor pendidikan masih belum dibuka dan tetap mengandalkan sistem pembelajaran daring. Lamanya pemberlakuan sistem daring dalam perkuliahan menimbulkan persoalan tersendiri terutama bagi aspek perekonomian daerah maupun keuangan Peguruan Tinggi Swasta (PTS). Oleh karena itu, bergulir wacana di media massa tentang kemungkinan pemberlakuan kuliah tatap muka (luring) pada tahun ajaran baru 2020.

Kebijakan penanganan pandemi seringkali harus menghadapi dilema antara mendahulukan sektor ekonomi atau memprioritaskan sektor kesehatan masyarakat. Dilema ini muncul akibat sifat virus yang mudah menular antar manusia sehingga banyak negara di dunia menerapkan kebijakan karantina wilayah (lockdown). Kebijakan karantina ini menyebabkan banyak kantor dan perusahaan menerapkan bekerja di rumah bagi para karyawannya, melakukan pemutusan hubungan kerja akibat terganggunya supply chain, menutup tempat-tempat publik seperti 
tempat wisata, pusat perbelanjaan, bioskop, pasar dan sebagainya. Hal ini menimbulkan stagnasi perekonomian. Di sisi lain, jika pemerintah tidak melakukan karantina dan pembatasan sosial, maka penularan virus akan terjadi dengan cepat dan masif sehingga tenaga medis yang tersedia tidak mampu menangani wabah.

Dalam konteks dilema kebijakan pandemi tersebut, framing media menjadi menarik untuk dikaji. Media sebagai pilar keempat demokrasi memiliki tanggung jawab mengawal kebijakan-kebijakan pemerintah demi kepentingan masyarakat. Idealnya, media harus berpijak pada obyektivitas dalam memberitakan Covid-19 sehingga media semestinya menghadirkan beragam perspektif: kesehatan masyarakat, ekonomi, epidemilogi, hak asasi dan sebagainya. Namun media juga kerap menjadi alat bagi pemerintah, korporasi atau lembaga non pemerintah untuk menitipkan framing atas suatu isu tertentu, termasuk dalam pemberitaan kebijakan Covid-19.

Pers memiliki peran strategis dalam masa pandemi khususnya dalam memberitakan kebijakan-kebijakan terkait pandemi. Pers dianggap memiliki kekuatan untuk memengaruhi proses kebijakan. Salah satu kekuatan pers ada pada kemampuannya untuk mengumpulkan informasi penting dan mengarahkan opini publik melalui pemberitaannya. Di sisi lain, opini publik saling berkait dengan proses formulasi kebijakan atau pengambilan keputusan yang dilakukan oleh pemerintah (Crow \& Lawlor, 2016). Opini publik dapat mengubah suatu kebijakan yang dilakukan oleh pemerintahan yang demokratis. Secara tidak langsung, formulasi kebijakan dapat dipengaruhi oleh pemberitaan pers. Media pers memberitakan suatu peristiwa atau isu dengan framing tertentu untuk mengarahkan opini publik sesuai agenda settingnya.

Di masa normal baru, media memiliki pilihan untuk memposisikan diri melalui agenda setting dan framing pemberitaannya. Kondisi yang ideal adalah jika media memberitakan kebijakan masa pandemi dengan fokus pada komunikasi risiko dan pemberitaan yang objektif dan berimbang. Namun pada prakteknya, pemberitaan media atas peristiwa dan isu terkait Covid-19 bisa jadi sangat bias pada sudut pandang tertentu, tergantung pada agenda media, yang tidak jarang memiliki perbedaan dengan agenda publik. Ketidak-objektifan tersebut juga dilakukan media, sadar atau tidak, dengan membangun framing tertentu atas isu atau persoalan publik terkait pandemi Covid-19.

Artikel ini memaparkan hasil penelitian terhadap berita-berita koran Kedaulatan Rakyat dalam membingkai (framing) perkuliahan di masa normal baru pandemi Covid-19. Penelitian ini bertujuan untuk mengetahui bagaimana koran lokal terbesar di Yogyakarta membingkai (framing) perkuliahan tatap muka di Yogyakarta. Selain itu, penelitian ini juga mengeksplorasi teks berita untuk memperoleh pendefinisian masalah, diagnosis penyebabnya, pembuatan penilaian dan saran atas solusinya.

Topik penelitian mengenai pandemi sudah cukup banyak dibahas di dalam jurnal ilmiah lain termasuk melalui penelitian framing pemberitaan media. Namun lokus dan fokus dalam riset ini sangat spesifik dan belum pernah dilakukan sebelumnya. Penelitian framing perkuliahan tatap muka di masa normal baru dalam sektor pendidikan tinggi di Yogyakarta belum didapati di dalam publikasi jurnal-jurnal internasional maupun nasional. Oleh karena itu, hasil penelitian dalam artikel ini akan memberikan kontribusi pengetahuan tentang bagaimana suatu koran lokal yang paling berpengaruh memilih frame berita terkait perkuliahan daring pendidikan tinggi di DIY.

Sejak kasus pertama Covid-19 ditemukan di Indonesia, pemerintah segera mengambil kebijakan untuk sektor pendidikan. Pemerintah pusat memutuskan untuk menutup sekolahsekolah dan kampus-kampus dan mengubah semua kegiatan pendidikan dalam bentuk daring. Pemerintah melalui Kementerian Pendidikan merumuskan tiga kebijakan pendidikan di masa 
pandemi.

Kebijakan ideal untuk pendidikan di saat pandemi adalah kebijakan yang fokus pada kesehatan dan keselamatan serta tetap memelihara kualitas pendidikan. Fokus pada kesehatan artinya kegiatan-kegiatan dalam dunia pendidikan harus menerapkan protokol kesehatan yang ketat untuk mencegah meluasnya wabah terutama dari klaster sekolah atau kampus. Pembelajaran daring menjadi pilihan utama karena cara tersebut mampu meminimalkan kontak antar manusia dan tidak menimbulkan kerumunan yang menjadi faktor pemicu penyebaran virus Covid-19. Di sisi lain, kualitas pendidikan tidak boleh dikesampingkan. Meskipun daring, kualitas belajar-mengajar harus mampu mencapai target yang sama dengan saat normal. Oleh karena itu, berbagai panduan pembelajaran daring dikeluarkan oleh Kementerian Pendidikan maupun oleh sekolah-sekolah dan kampus-kampus, mulai dari pengembangan platform digital, penyesuaian kurikulum hingga inovasi pembelajaran daring.

Kementerian Pendidikan dan Kebudayaan Republik Indonesia telah mengeluarkan beberapa kebijakan pendidikan dalam masa normal baru pandemi Covid ini. Pelaksanaan program dan kegiatan pada masa adaptasi kebiasaan baru di sektor pendidikan mengutamakan kesehatan dan keselamatan mahasiswa, dosen, tenaga kependidikan serta masyarakat ("Ini Tiga Kebijakan Untuk Perguruan Tinggi Dalam Era New Normal,” 2020). Aspek kesehatan dan keselamatan menjadi tujuan utama kebijakan pendidikan di masa normal baru supaya kampus tidak menjadi klaster penularan Covid-19. Terdapat tiga kebijakan bidang pendidikan yang dikeluarkan kementerian pada Juni 2020 (Putra, 2020). Pertama, tentang pelaksanaan tahun akademik baru. Tahun akademik 2020/ 2021 tetap dimulai sesuai kalender yaitu Agustus 2020. Kedua, kebijakan mengenai proses pembelajaran. Selama masa normal baru, kampus-kampus diharapkan melakukan pembelajaran daring. Untuk praktikum yang sulit dilaksanakan secara daring, Kemdikbud menyarankan supaya praktikum dilakukan di akhir semester. Ketiga, arahan kepada para pimpinan universitas dalam pemberian izin kegiatan-kegiatan luring di kampus. Izin diberikan apabila kegiatan dilaksanakan dengan protokol kesehatan dan kegiatan tersebut sangat mendesak sehingga tidak dapat dilakukan dengan daring. Protokol kesehatan merujuk pada kebijakan Kementerian Kesehatan yaitu pembatasan jumlah orang dalam satu ruangan, pemakaian masker, penyediaan fasilitas cuci tangan atau hand sanitizer dan pengaturan jarak fisik. Pihak universitas disarankan segera mengubah layanan akademik dan perpustakaan ke bentuk daring termasuk kegiatan ospek dan wisuda.

Namun kemudian banyak persoalan muncul ketika pembelajaran daring diterapkan. Dalam konteks Indonesia, persoalan utama penerapan pembelajaran daring di sektor pendidikan tinggi adalah pada biaya terhadap akses internet akibat kondisi ekonomi masyarakat. Meskipun akses internet penduduk Indonesia mencapai 150 juta jiwa dengan penetrasi 56\% yang tersebar diseluruh wilayah, tetapi data tersebut tidak menjamin bahwa pengguna internet mampu terus menerus menyediakan data internet untuk melakukan pembelajaran daring. Hal ini menyebabkan banyak mahasiswa mengeluhkan biaya yang harus dikeluarkan ketika mereka harus sering mengakses internet untuk kuliah daring melalui aplikasi-aplikasi seperti Zoom dan Google Meet yang boros kuota.

Untuk konteks di Yogyakarta, perkuliahan daring juga menimbulkan implikasi bagi perekonomian masyarakat. Keberadaan mahasiswa dari luar Yogyakarta mampu menghidupkan perekonomian masyarakat. Banyak usaha kecil yang menjadikan mahasiswa sebagai target pasarnya seperti usaha indekos, laundri, fotokopi, warung makan, kedai kopi, toko kelontong hingga ojek daring. Selain itu, pemasukan daerah secara tidak langsung terimbas oleh sepinya kegiatan pariwisata dan pendidikan. Pemasukan daerah Yogyakarta sangat bergantung dari sektor pajak dan retribusi daerah yang disumbang oleh sektor pendidikan tinggi dan pariwisata. 
196 | Kajian Jurnalisme

Volume 04 Nomor 02 Tahun 2021

DOI: $10.24198 / \mathrm{jkj} . \mathrm{v} 4 \mathrm{i} 2.31300$

Diskusi mengenai sikap pers dalam memberitakan pandemi sebenarnya tidak jauh berbeda dengan diskusi mengenai pemberitaan pers tentang bencana dan konflik. Keberpihakan dan posisi pers dinilai dari caranya mengagendakan isu dan membingkainya (framing). Posisi pers juga dapat dinilai melalui analisis beritanya. Ekspektasi publik terhadap pers adalah supaya pers dapat menginformasikan resiko-resiko wabah, menginformasikan kebijakan penanggulangan wabah, mendukung tranparansi situasi wabah dan menjadi watchdog atas kebijakan-kebijakan pemerintah sehingga kesehatan dan keselamatan masyarakat menjadi fokus utama (Pieri, 2019).

Secara normatif, media di masa pandemi berfungsi menginformasikan fakta terkait wabah dengan transparan dan objektif, mengkomunikasikan semua resiko penyakit dan memuat edukasi dan persuasi untuk mendukung komunikasi kesehatan masyarakat (Mejia et al., 2020) it is important to measure whether the population is receiving information that calms it down, as well as whether such news are in accordance with the magnitude of the issue. Objective: To validate a questionnaire that measures the perception of the media and their informative role in the face of COVID-19 pandemic. Methods: A validation process for a questionnaire that measures the perception of the magnitude of this issue and whether it generates fear was carried out. The validation was performed by means of a literature search. Moreover, a first version of the scale was developed, which was assessed by 30 experts (physicians, epidemiologists, among others. Media seharusnya memberitakan perkembangan pandemi dengan proporsional dan berimbang. Misalnya tidak hanya fokus pada jumlah orang yang terinfeksi namun juga mampu mengeksplorasi dan membantu masyarakat untuk melakukan pengawasan terhadap kebijakan yang diambil pemerintah dalam penanggulangan wabah.

"Newspaper media coverage (in print or online), especially that produced through national channels in the West, continues to remain central to the framing of public and policy debates there on national security and health emergencies, like pandemics" (Dry \& Leach, 2010).

Dalam mengkomunikasikan kebijakan terkait wabah, tranparansi dan obyektivitas menjadi salah satu kunci keberhasilan pencegahan dan penanganan wabah (Michael, 2020). Di sinilah media dapat mengambil peran penting. Apalagi saat ini media sosial menjadi salah satu medium penyebar hoaks dan disinformasi terkait wabah. Media massa dapat mendukung terciptanya informasi yang jujur dan benar melalui berita-beritanya sehingga membantu masyarakat untuk melawan hoaks.

Media juga diharapkan selalu merujuk pada perspektif ilmiah sebagai kerangka pemberitaan. Media tidak seharusnya malah membahas mitos dan teori konspirasi sebagai sudut pandang dalam memberitakan wabah. Jurnalisme yang berpijak pada data dan fakta adalah kewajiban, dan memilih sudut pandang yang rasional dan ilmiah memang merupakan pilihan, namun hal tersebut adalah pilihan yang positif. Di tengah masyarakat Indonesia yang masih sangat percaya mitos, berita yang saintifik akan memberi edukasi terhadap masyarakat sehingga resiko-resiko penyakit dan pencegahannya dapat dikomunikasikan kepada publik (Dry \& Leach, 2010). Media memang harus memiliki tanggung jawab mengedukasi masyarakat karena bagaimanapun juga, media hidup dari masyarakat.

Sudah banyak riset terkait media dan pandemi yang dipublikasikan di jurnal-jurnal internasional maupun nasional. Riset-riset tersebut mengungkap framing media atas kebijakan penanganan wabah, framing media atas kebijakan lockdown, analisis wacana politisasi pandemi dan masih banyak lagi. Dalam konteks pandemi Covid-19 di Indonesia, riset-riset media juga sudah banyak yang dipublikasikan di jurnal-jurnal.

Sampai pada bulan September 2020, terdapat beberapa penelitian framing media dan Covid-19. Salah satunya adalah riset framing media dalam memberitakan Covid-19 berdasarkan 
kerangka komunikasi resiko dan kesehatan. Riset tersebut mengeksplorasi bagaimana framing berita tentang Covid-19 oleh Koran KOMPAS selama bulan Januari 2020. Dalam komunikasi risiko, media berperan menyampaikan dinamika informasi terkait suatu penyakit atau wabah. Pada periode awal Januari, KOMPAS menampilkan berita yang masih terbatas memuat komunikasi kesehatan (Wibhisono, 2020)e.g., risk preparedness and clear information to reduce uncertainties. At the end of 2019, the world was once again confronted with a health-threatening situation: the emergence of the novel coronavirus. Media can construct health risk information through narratives or stories they provide. Nevertheless, not every pandemic represented was equal. The media could build risk perception about global or local outbreaks. In light of that, this article aims to describe how the media in Indonesia framed the novel coronavirus disease issue (COVID-19. Di awal isu Covid-19 mencuat di media global, KOMPAS membingkai isu tersebut dengan konsekuensi, health severity, tanggung jawab, aksi dan ketidakpastian. Framing berita KOMPAS pada periode selanjutnya berkembang dengan adanya perspektif medis dan human interest. KOMPAS mengarahkan pemberitaan Covid-19 kepada Pemerintah agar Pemerintah segera mengeluarkan kebijakan supervisi, antisipasi dan evakuasi.

Penelitian berita Covid-19 lainnya adalah analisis diskursif atas persepsi Media TEMPO tentang penanganan Pemerintah Indonesia dalam menghadapi pandemi. Riset ini mengungkap bahwa berita-berita TEMPO terkait penanganan Covid-19 cenderung bersifat kritis (Mintarsih, Kodrat, \& Emiliasari, 2020). Orang-orang di dalam redaksi TEMPO yang tidak merupakan bagian dari pemerintah diinterpretasikan memengaruhi posisi pemberitaan TEMPO . TEMPO bebas menempatkan diri sebagai watchdog yang kerap memberi kritik dan sindiran terhadap penanganan pemerintah atas pandemi. Pada level analisis sosiokultural, wacana yang muncul dalam pemberitaan tidak netral namun memiliki kekuatan ideologis. TEMPO menempatkan narasumber dan subjek yang mewakili suara pemerintah sebagai pihak negatif dari kelompok dominan. Pemerintah dikonstruksi sebagai pihak yang tidak becus menangani pandemi Covid-19.

\section{METODE}

Penelitian ini dilakukan untuk menjawab pertanyaan, "Bagaimana koran lokal Kedaulatan Rakyat membentuk framing wacana perkuliahan tatap muka di Yogyakarta dalam pemberitaannya?". Untuk memperoleh jawabannya maka penelitian ini menggunakan metode analisis framing. Analisis framing digunakan untuk meneliti teks berita, baik narasi maupun visualnya, berlandaskan paradigma interpretif. Metode ini bertujuan mengeksplorasi teks berita untuk menemukan pola atau struktur tertentu yang dapat menjelaskan narasi dan pesan utama berita tersebut, dan menjelaskannya secara mendalam (Dirikx \& Gelders, 2010)many articles mention the need for urgent actions, refer to possible solutions and suggest that governments are responsible for and/or capable of alleviating climate change problems (responsibility frame.

Framing merupakan proses yang terikat erat dengan agenda setting. Jika agenda setting merupakan proses pertama dimana media memilih isu atau peristiwa yang dianggap penting untuk menjadi agenda media, maka framing merupakan aksi selanjutnya.

"..to frame is to "select some aspects of a perceived reality and make them more salient in a communicating text, in such a way as to promote a particular problem definition, causal interpretation, moral evaluation, and/or treatment recommendation" (Entman, 1993).

Dengan demikian, Entman mendefinisikan framing sebagai proses pemilihan beberapa elemen dari realitas dan penghimpunan satu narasi yang menyoroti keterkaitan antar elemenelemen tersebut untuk mengarahkan pada interpretasi tertentu. 
198 | Kajian Jurnalisme

Volume 04 Nomor 02 Tahun 2021

DOI: $10.24198 / \mathrm{jkj} . \mathrm{v} 4 \mathrm{i} 2.31300$

Analisis framing model Robert Entman adalah suatu metode penelitian untuk menginterpretasikan persepsi media atas suatu peristiwa atau isu tertentu. Interpretasi tersebut dilakukan terhadap narasi dan gambar di dalam berita media. Berita memuat narasi peristiwa dan fakta-fakta yang terstruktur. Narasi dan fakta tersebut dibangun melalui pemilihan narasumber, keberpihakan (standpoint) narasumber atas peristiwa atau isu yang diangkat, keterkaitan narasumber dengan isu yang diberitakan, dan sebagainya. Framing menekankan pada dua aspek yaitu seleksi isu dan salience.

Penelitian ini menggunakan analisis framing yang diformulasikan oleh Robert Entman. Analisis framing model ini menggunakan pendekatan interpretif dan analitik. Penekanan analisis framing versi Entman terletak pada penggunaan perangkat retoris (rhetorical device) sebagaimana dia sebutkan:

"Rhetorical devices include word choice, metaphors, and exemplars. Other devices that can be examined are: the presence or absence of certain keywords, stock phrases, sources of information, and sentences that provide thematically reinforcing clusters of facts or judgement" (Entman, 1993).

Perangkat retoris terdiri dari pilihan kata, metafora, dan contoh-contoh dalam kalimat. Selain itu, perangkat lain yang dapat diuji adalah ada atau tidaknya kata-kata kunci tertentu, frasa, sumber informasi dan kalimat-kalimat yang memperkuat klaster-klaster fakta secara tematis. Perangkat retoris di dalam teks berita tersebut yang menjadi fokus analisis dalam metode framing analisis model Entman.

Terdapat empat indikator yang mengindikasikan bahwa suatu teks berita memiliki framing tertentu (Entman, 1993). Pertama, berita memuat definisi persoalan (define problems). Kedua, terdapat diagnosis penyebab persoalan (diagnose causes). Ketiga, di dalam berita ditemukan evaluasi moral atas persoalan atu isu yang diangkat (moral evaluation). Dan keempat, narasi berita mengandung solusi atas isu atau persoalan tersebut (suggest remedies). Keempat aspek tersebut yang akan digunakan untuk menganalisis berita-berita yang menjadi sampel penelitian ini.

Pemberitaan Kedaulatan Rakyat (KR) dipilih sebagai objek penelitian mengingat reputasi media tersebut yang sudah sangat baik dan populer. Kedaulatan Rakyat memiliki tiras terbanyak di Yogyakarta dan Jawa Tengah (Syaifulloh \& Idhom, 2015). Sebagai suatu institusi media lokal yang cukup berpengaruh, Kedaulatan Rakyat memiliki kekuatan untuk melakukan kontrol sosial, menjadi medium komunikasi politik maupun sumber pertimbangan para pembuat kebijakan daerah. Berita-berita yang menjadi sampel penelitian ini adalah semua berita dari harian KR yang memuat isu pembukaan perkuliahan di pendidikan tinggi dalam medio Juni sampai September 2020.

Terdapat tujuh berita yang menjadi obyek penelitian ini. Ketujuh berita tersebut dipilih atas dasar dua kriteria utama yaitu: pertama, merupakan berita-berita di dalam suratkabar Kedaulatan Rakyat yang terkait dengan wacana pembukaan kembali perkuliahan tatap muka di Perguruan Tinggi di Daerah Istimewa Yogyakarta, dan kedua, berita-berita tersebut diterbitkan pada masa normal baru yang dimulai pada Juli 2020.

Data yang diperoleh kemudian dianalisis sesuai alur interpretasi teks berita versi Entman. Sebuah teks setidaknya harus memiliki satu dari empat fungsi framing, seperti dijelaskan di dalam tabel operasionalisasi di bawah ini:

Adapun unit analisis dari objek penelitian ini adalah keseluruhan teks berita yang terdiri dari judul, lead dan tubuh berita. Pengumpulan data primer dilakukan dengan cara kualitatif yaitu dengan melakukan koding teks berita kemudian menginterpretasikan kata, frasa dan kalimat di dalamnya. Penginterpretasian tersebut menggunakan perangkat retoris sebagaimana 
Volume 04 Nomor 02 Tahun 2021

DOI: $10.24198 /$ jkj.v4i2.31300

telah dipaparkan di bagian sebelum ini.

Tabel 1. Judul dan Lead Berita Kedaulatan Rakyat tentang Perkuliahan Tatap Muka di Masa Normal Baru

\begin{tabular}{|l|l|}
\hline \multicolumn{1}{|c|}{ Elemen Framing } & \multicolumn{1}{c|}{ Definisi } \\
\hline Define Problems. & $\begin{array}{l}\text { Bagaimana peristiwa atau isu yang menjadi topik berita dipandang } \\
\text { sebagai masalah. }\end{array}$ \\
\hline Diagnose Causes & Penyebab atau aktor yang dianggap sebagai penyebab masalah. \\
\hline $\begin{array}{l}\text { Make Moral Judgement/ } \\
\text { Evaluation. }\end{array}$ & $\begin{array}{l}\text { Nilai moral yang ingin disampaikan } \\
\text { melalui berita. }\end{array}$ \\
\hline $\begin{array}{l}\text { Suggest Solutions/ } \\
\text { Remedies. }\end{array}$ & Solusi yang ditawarkan untuk menyelesaikan masalah. \\
\hline
\end{tabular}

Sumber: Data Diolah oleh Peneliti (2020)

\section{HASIL DAN PEMBAHASAN}

Analisis framing dilakukan untuk menjelaskan bagaimana Kedaulatan Rakyat membingkai (to frame) wacana pembukaan perkuliahan tatap muka di Yogyakarta. Dalam periode 2 bulan - Juli sampai dengan September 2020 - Kedaulatan Rakyat cukup intens mengangkat topik wacana pembukaan kembali perkuliahan tatap muka di Daerah Istimewa Yogyakarta (DIY). Hasil analisis menunjukkan bahwa pemberitaan Kedaulatan Rakyat terkait topik perkuliahan daring memuat unsur-unsur framing. Hasil penelitian dan pembahasan tersebut diuraikan di dalam sub-bab di bawah ini.

\section{Perkuliahan Daring Menjadi Penyebab Kontraksi Ekonomi di Yogyakarta}

Penelitian ini menggunakan kerangka analisis Robert Entman. Setiap teks berita dianalisis menggunakan perangkat retoris untuk dapat mengidentifikasi apakah terdapat minimal satu dari empat elemen framing model Entman. Hasil analisis dijabarkan ke dalam dua tabel terpisah supaya pemaparan lebih terperinci. Tabel pertama merupakan penjabaran atas temuan aspek pendefinisian masalah (define problems) dan diagnosis penyebab masalah (diagnose causes), seperti berikut ini:

Dari ketujuh berita yang dianalisis (tabel 2), terdapat pola yang secara umum sama. Kedaulatan Rakyat menampilkan narasi yang diulang-ulang yang menyatakan bahwa "sektor pendidikan tinggi adalah lokomotif perekonomian daerah". Sebagian besar pendefinisian masalah (define problems) adalah tentang keterpurukan perekonomian di Daerah Istimewa Yogyakarta. Sementara itu, penyebabnya (diagnose causes) adalah karena penerapan kuliah daring oleh semua kampus yang berada di Yogyakarta, yang mengakibatkan para mahasiswa pendatang kembali ke daerah masing-masing.

Data ekonomi digunakan sebagai basis argumentasi pada pemberitaan di awal masa normal baru. Penyajian angka-angka terkait resesi, kontraksi ekonomi daerah dan pertumbuhan ekonomi daerah yang melambat dapat membangun tone negatif yang cenderung mampu menarik perhatian khalayak. Apalagi data negatif tersebut diberitakan dalam frekuensi yang cukup sering. Secara psikologis, manusia memang memiliki atensi yang lebih terhadap peristiwa atau berita buruk. Oleh karena itu, peristiwa-peristiwa dan isu-isu negatif pun memiliki nilai berita yang tinggi sehingga muncul istilah bad news is a good news. Peristiwa atau isu yang cenderung negatif terbukti dapat menarik perhatian khalayak sekaligus dapat menjadi alat untuk memengaruhi persepsi publik (Soroka, 2014). 
DOI: $10.24198 / \mathrm{jkj} . \mathrm{v} 4 \mathrm{i} 2.31300$

Tabel 2. Pendefinisian Masalah dan Diagnosis Penyebab Masalah

\begin{tabular}{|c|c|c|c|}
\hline Tanggal & Judul & Define Problems & Diagnose Causes \\
\hline 26 Juli 2020 & $\begin{array}{l}\text { Bangkitkan Perekonomian } \\
\text { DIY. Kuliah Tatap Muka } \\
\text { Harus Dibuka Bertahap. }\end{array}$ & $\begin{array}{l}\text { Pariwisata dan pendidikan } \\
\text { menjadi "lokomotif" } \\
\text { penggerak perekonomian } \\
\text { DIY, namun terhenti akibat } \\
\text { pandemi. }\end{array}$ & $\begin{array}{l}\text { Perkuliahan daring } \\
\text { menghambat laju } \\
\text { perekonomian daerah. }\end{array}$ \\
\hline 2 Agustus 2020 & $\begin{array}{l}73 \text { Persen Mahasiswa PTS } \\
\text { Pulang Kampung. Potensi } \\
\text { DIY Berkurang Rp } 27 \\
\text { miliar Perhari. }\end{array}$ & $\begin{array}{l}\text { Potensi uang beredar di DIY } \\
\text { berkurang hingga } 27 \text { miliar } \\
\text { per hari. }\end{array}$ & $\begin{array}{l}\text { Pandemi membuat kampus } \\
\text { melaksanakan perkuliahan } \\
\text { daring sehingga } 77 \% \\
\text { mahasiswa di DIY pulang } \\
\text { kampung. }\end{array}$ \\
\hline 3 Agustus 2020 & $\begin{array}{l}\text { Yogya Hadapi Dilema } \\
\text { Kembalinya Mahasiswa. } \\
\text { Kampus Jangan Paksakan } \\
\text { Tatap Muka. }\end{array}$ & $\begin{array}{l}\text { Pergerakan ekonomi warga } \\
\text { DIY terganggu. }\end{array}$ & $\begin{array}{l}\text { Pandemi membuat } \\
\text { perkuliahan harus } \\
\text { dilaksanakan daring } \\
\text { sehingga mahasiswa } \\
\text { sebagai sumber penggerak } \\
\text { ekonomi DIY, harus pulang } \\
\text { kampung. }\end{array}$ \\
\hline 6 Agustus 2020 & $\begin{array}{l}\text { Cegah Resesi DIY Makin } \\
\text { Parah. Hidupkan Pariwisata } \\
\text { dan Pendidikan Secara } \\
\text { Bertahap. }\end{array}$ & $\begin{array}{l}\text { Pertumbuhan ekonomi DIY } \\
\text { minus } 6,74 \% \text { pada triwulan } \\
\text { kedua } 2020 \text {. }\end{array}$ & $\begin{array}{l}\text { Pertumbuhan ekonomi } \\
\text { minus akibat terhentinya } \\
\text { mobilitas wisatawan dan } \\
\text { mahasiswa ke Yogyakarta. }\end{array}$ \\
\hline 9 Agustus 2020 & $\begin{array}{l}\text { Pendidikan Merupakan } \\
\text { Lokomotif Perekonomian. } \\
\text { Kampus Diharap Segera } \\
\text { Lakukan Perkuliahan. }\end{array}$ & $\begin{array}{l}\text { Pada kuartal } 2 \text { tahun } \\
2020 \text { perekonomian DIY } \\
\text { mengalami kontraksi hingga } \\
6,74 \% \text {. }\end{array}$ & $\begin{array}{l}\text { Perekonomian DIY } \\
\text { melambat karena } \\
\text { berkurangnya jumlah } \\
\text { mahasiswa yang tinggal di } \\
\text { DIY. }\end{array}$ \\
\hline $\begin{array}{l}14 \text { September } \\
2020\end{array}$ & $\begin{array}{l}\text { Kuliah Tatap Muka Saat } \\
\text { Pandemi Covid 19. Kampus } \\
\text { Wajib Punya Gugus Tugas. }\end{array}$ & $\begin{array}{l}\text { Gugus Tugas Covid } \\
19 \text { DIY mengharuskan } \\
\text { pembentukan Gugus Tugas } \\
\text { Covid } 19 \text { di setiap kampus } \\
\text { untuk mencegah penularan } \\
\text { klaster kampus. }\end{array}$ & $\begin{array}{l}\text { Adanya beberapa PTS di } \\
\text { DIY yang akan menerapkan } \\
\text { kuliah tatap muka di awal } \\
\text { tahun akademik } 2020 .\end{array}$ \\
\hline $\begin{array}{l}15 \text { September } \\
2020\end{array}$ & $\begin{array}{l}\text { Sultan Minta Kampus } \\
\text { Gunakan Jogja Pass. Gugus } \\
\text { Tugas Kampus Harus } \\
\text { Efektif. }\end{array}$ & $\begin{array}{l}\text { Gugus Tugas Kampus harus } \\
\text { benar-benar mengontrol } \\
\text { secara periodik pelaksanaan } \\
\text { perkuliahan tatap muka } \\
\text { sesuai standar kesehatan. }\end{array}$ & $\begin{array}{l}\text { Pelaksanaan kuliah tatap } \\
\text { muka di masa pandemi } \\
\text { harus mengedepankan } \\
\text { protokol kesehatan yang } \\
\text { ketat. }\end{array}$ \\
\hline
\end{tabular}

Sumber: Data Diolah oleh Peneliti (2020)

Penyajian data ekonomi yang negatif tersebut tidak disertai dengan keberimbangan dengan data kesehatan terkait dampak Covid-19 jika perkuliahan tatap muka dilakukan. Absennya data tentang keterkaitan pembukaan kampus dan risiko penularan Covid-19 menjadikan framing terindikasi dengan kuat. Bias perspektif adalah salah satu indikasi framing berita yang dilakukan dengan sengaja maupun tidak oleh media pers. Apabila perspektif atas suatu peristiwa atau isu tertentu memang disengaja, maka terdapat beberapa indikasi, yaitu pertama, menampilkan narasumber dari satu pihak saja, kedua, menampilkan data untuk mendukung satu argumentasi saja, dan ketiga, menyajikan informasi yang tidak lengkap untuk menyembunyikan informasi lain yang seharusnya memberi keberimbangan perspektif. Dengan demikian, penyajian data 
Volume 04 Nomor 02 Tahun 2021

DOI: $10.24198 /$ jkj.v4i2.31300

yang hanya satu perspektif saja dapat menjadikan sebuah berita menjadi sangat bias (Entman, 2007). Adapun uraian data ekonomi tersebut dijabarkan di dalam tabel berikut ini:

Tabel 3. Data Data Pendukung di Dalam Pemberitaan Perkuliahan Tatap Muka

\begin{tabular}{|c|c|c|}
\hline Tanggal & Judul & Data \\
\hline 26 Juli 2020 & $\begin{array}{l}\text { Bangkitkan Perekonomian DIY. Kuliah } \\
\text { Tatap Muka Harus Dibuka Bertahap. }\end{array}$ & $\begin{array}{l}\text { - UMKM di Yogyakarta bertumpu pada } \\
\text { sektor pendidikan dan pariwisata dan } \\
\text { menyumbang } 98 \% \text { perekonomian } \\
\text { daerah. } \\
\text { - } 79 \% \text { tenaga kerja DIY terserap di } \\
\text { UMKM. } \\
\text { - Usulan supaya Pemda memberi } \\
\text { insentif ke kampus-kampus. }\end{array}$ \\
\hline 2 Agustus 2020 & $\begin{array}{l}73 \text { Persen Mahasiswa PTS Pulang } \\
\text { Kampung. Potensi DIY Berkurang Rp } \\
27 \text { miliar Perhari. }\end{array}$ & $\begin{array}{l}\text { - Potensi uang beredar di DIY bisa } \\
\text { berkurang } 27 \text { miliar per hari jika } \\
\text { semua mahasiswa pendatang } \\
\text { meninggalkan DIY. } \\
\text { - Belanja mahasiswa di DIY } \\
\text { berkontribusi 16,6 triliun per tahun } \\
\text { terhadap ekonomi, di bawah belanja } \\
\text { wisatawan yang mencapai } 20 \text { triliun. }\end{array}$ \\
\hline 3 Agustus 2020 & $\begin{array}{l}\text { Yogya Hadapi Dilema Kembalinya } \\
\text { Mahasiswa. Kampus Jangan Paksakan } \\
\text { Tatap Muka. }\end{array}$ & $\begin{array}{l}\text { - Terdapat } 300 \text { ribu lebih mahasiswa } \\
\text { PTS di DIY. }\end{array}$ \\
\hline 6 Agustus 2020 & $\begin{array}{l}\text { Cegah Resesi DIY Makin Parah. } \\
\text { Hidupkan Pariwisata dan Pendidikan } \\
\text { Secara Bertahap. }\end{array}$ & $\begin{array}{l}\text { - Pertumbuhan ekonomi DIY minus } \\
6,74 \% \text { pada triwulan II } 2020 \text {. }\end{array}$ \\
\hline 9 Agustus 2020 & $\begin{array}{l}\text { Pendidikan Merupakan Lokomotif } \\
\text { Perekonomian. Kampus Diharap Segera } \\
\text { Lakukan Perkuliahan. }\end{array}$ & $\begin{array}{l}\text { - Kontraksi ekonomi DIY cukup dalam } \\
\text { mencapai } 6 \% \text {. } \\
\text { - Capaian pertumbuhan ekonomi } \\
\text { minus pada dua kuartal berturut-turut } \\
\text { menyebabkan resesi daerah. }\end{array}$ \\
\hline 14 September 2020 & $\begin{array}{l}\text { Kuliah Tatap Muka Saat Pandemi Covid } \\
\text { 19. Kampus Wajib Punya Gugus Tugas. }\end{array}$ & - Tidak memuat data statistik. \\
\hline 15 September 2020 & $\begin{array}{l}\text { Sultan Minta Kampus Gunakan Jogja } \\
\text { Pass. Gugus Tugas Kampus Harus } \\
\text { Efektif. }\end{array}$ & - Tidak memuat data statistik. \\
\hline
\end{tabular}

Sumber: Data Diolah oleh Peneliti (2020)

Selain data, latar belakang narasumber yang muncul di dalam pemberitaan juga timpang. Narasumber atau informan adalah sumber berita yang memiliki relevansi erat dengan peristiwa atau isu yang diangkat. Idealnya, dalam isu kebijakan normal baru di dunia pendidikan tinggi, narasumber yang sangat terkait bukan hanya pihak berwenang dari ahli pendidikan dan regulator pendidikan saja, namun juga narasumber dari sektor kesehatan seperti dokter, epidemiolog, Gugus Tugas Covid-19, ekonom dan sosiolog. Faktanya, narasumber yang menjadi sumber informasi dalam berita-berita tentang kebijakan pendidikan tinggi di masa normal baru lebih didominasi oleh elite dan ahli ekonomi seperti penjelasan dalam tabel 4.

Informasi di dalam tabel di atas menunjukkan bahwa jumlah narasumber yang paling dominan berasal dari kelompok ahli ekonomi dan para pejabat Perguruan Tinggi. Fakta ini menjelaskan bahwa pemberitaan Kedaulatan Rakyat tidak menyeimbangkan perspektif 
pemberitaan dengan menampilkan informasi dari narasumber yang memiliki pengetahuan tentang epidemiologi, kesehatan masyarakat dan mikrobiologi. Absennya suara dari pihak yang justru paling terdampak seperti pelaku UMKM, dosen, dokter dan mahasiswa membuat berita-berita tersebut sangat tidak berimbang.

Tabel 4. Jumlah Total Narasumber Berita Berdasarkan Latar Belakangnya

\begin{tabular}{|c|c|c|c|}
\hline No & Kategori Informan & Jumlah & Keterangan \\
\hline 1 & Ahli ekonomi & 5 & $\begin{array}{l}\text { Deputi Perwakilan BI Yogyakarta } \\
\text { Ketua ISEI } \\
\text { Kepala BPS DIY } \\
\text { Dosen UPN Veteran Yogyakarta } \\
\text { Kepala Pusat Studi Keuangan UPN Veteran Yogyakarta }\end{array}$ \\
\hline 2 & Pejabat Pendidikan Tinggi & 5 & $\begin{array}{l}\text { Ketua Aptisi Wilayah V } \\
\text { Kepala Lembaga Layanan PT Wilayah V } \\
\text { WR II UGM } \\
\text { Rektor UWM } \\
\text { Lembaga Layanan PT Wilayah V }\end{array}$ \\
\hline 3 & $\begin{array}{l}\text { Pemerintah Pusat dan atau } \\
\text { Pemerintah Daerah }\end{array}$ & 4 & $\begin{array}{l}\text { Sekda DIY } \\
\text { Sekda DIY } \\
\text { Kepala Satpol DIY } \\
\text { Gubernur DIY }\end{array}$ \\
\hline 4 & Legislatif & 3 & $\begin{array}{l}\text { Wakil Ketua DPRD DIY } \\
\text { Anggota DPD RI Dapil DIY } \\
\text { Wakil Ketua DPR RI }\end{array}$ \\
\hline 5 & Dokter & 1 & Ketua IDI DIY \\
\hline 6 & Gugus Tugas Covid-19 & 1 & Wakil Sekretaris Gugus Tugas DIY \\
\hline 7 & Epidemolog & 0 & - \\
\hline 8 & Ahli Kesehatan Masyarakat & 0 & - \\
\hline 9 & Ahli Pendidikan & 0 & - \\
\hline 10 & Dosen & 0 & - \\
\hline 11 & Mahasiswa & 0 & - \\
\hline 12 & Pelaku usaha besar & 0 & - \\
\hline 13 & Pelaku UMKM & 0 & - \\
\hline 14 & Masyarakat umum & 0 & - \\
\hline
\end{tabular}

Sumber: Data Diolah oleh Peneliti (2020)

\section{Perguruan Tinggi adalah Pihak yang Ikut Bertanggung Jawab dalam Pemulihan Ekonomi Daerah}

Elemen framing lainnya adalah evaluasi moral (moral evaluation) dan saran penyelesaian masalah (suggest solution). Kedua aspek tersebut juga ditemukan di dalam teks-teks berita Kedaulatan Rakyat, meski terdapat teks berita yang tidak mengandung saran penyelesaian atau solusi masalah. Penjabaran secara rinci mengenai moral evaluation dan solution tersebut ada di dalam tabel berikut:

Berdasarkan penjelasan dalam tabel 4 di atas, sebagian besar teks berita memuat evaluasi moral yang senada. Penilaian moralnya adalah bahwa kampus-kampus harus segera membuka perkuliahan tatap muka. Narasi yang dibangun Kedaulatan Rakyat adalah kampus 
merupakan pihak yang ikut bertanggung jawab atas persoalan terpuruknya ekonomi daerah di Yogyakarta. Secara umum, pemberitaan Kedaulatan Rakyat menjadikan Perguruan Tinggi sebagai agensi yang memiliki kontribusi besar terhadap pergerakan ekonomi Yogyakarta. Di sisi lain, Pemerintah Daerah sebagai aktor yang paling berwenang dalam membuat kebijakan daerah justru tidak terlalu menjadi sorotan. Hanya terdapat dua narasi yang melibatkan Pemerintah Daerah yaitu pertama, Pemda sebagai pemberi insentif kepada kampus yang membuka kuliah tatap muka, dan kedua, Pemda sebagai fasilitator penyedia aplikasi Jogja Pass yang berfungsi untuk mendata mahasiswa pendatang. Menjadikan kampus sebagai pihak yang paling bertanggung jawab adalah bukti bahwa Kedaulatan Rakyat memang membangun framing tertentu.

\section{Advokasi Pembukaan Kembali Perkuliahan Tatap Muka di Yogyakarta}

Dalam hal solusi terhadap permasalahan (suggest solution/remedes), pemberitaan Kedaulatan Rakyat mengarah pada advokasi pembukaan perkuliahan tatap muka di Yogyakarta sesegera mungkin. Pemberitaan tidak memuat alternatif kebijakan lain yang mungkin dilakukan oleh Pemerintah Daerah selain hanya kembali pada situasi normal, tanpa membuka wacana adanya inovasi kebijakan lainnya untuk menggenjot perekonomian daerah yang sedang lesu. Meskipun di dalam teks berita didapati narasi mengenai prasyarat penerapan protokol kesehatan dan pembentukan Gugus Tugas Covid-19 di setiap kampus, namun kedua hal tersebut tetap merupakan kebijakan yang masih terkait dengan perkuliahan di lingkungan kampus. Pemberitaan Kedaulatan Rakyat tidak sampai mendalami bagaimana upaya pencegahan penularan Covid-19 pada lingkungan indekos atau asrama mahasiswa meskipun pada dasarnya jumlah mahasiswa pendatang yang mencapai angka puluhan ribu adalah permasalahan serius dalam penanggulangan wabah. Keterbatasan alternatif kebijakan tersebut selain membatasi alternatif kebijakan lain untuk memperbaiki perekonomian DIY, juga membatasi konteks permasalahan hanya terbatas pencegahan di lingkungan kampus, tidak sampai di lingkungan asrama atau indekos.

Batasan solusi permasalahan dan kebijakan tersebut mencerminkan bahwa media massa memiliki relasi erat dengan proses kebijakan publik. Media dapat berfungsi sebagai penyedia informasi tentang kebijakan-kebijakan yang dilakukan oleh pemerintah, baik pusat maupun daerah. Di sisi lain, media massa memiliki kekuatan untuk memengaruhi proses kebijakan publik. Istilah "media governs" (media memerintah) merupakan satu konsep yang muncul ketika suatu keputusan pemerintah berubah akibat tekanan media melalui pemberitaannya. Media melakukan peliputan suatu isu atau kebijakan dengan gencar dan framing yang kuat sehingga pemerintah sebagai pembuat keputusan kemudian mengubah kebijakannya (Entman, 2007).

Kemampuan media untuk memengaruhi keputusan pemerintah dalam merumuskan atau mengubah kebijakan ditentukan oleh beberapa kondisi. Salah satunya adalah cara media memberitakan suatu isu. Proses agenda setting, priming dan framing merupakan rangkaian produksi berita yang menentukan agenda media, yang kemudian berpotensi menjadi agenda publik (Moy, Tewksbury, \& Rinke, 2016). Kekuatan media didapat dari konsistensinya dalam melakukan ketiga langkah tersebut. Aspek lain yang memengaruhi pendapat publik selain dari framing itu sendiri adalah pada konsistensi dan frekuensi terpaan berita pada publik. Proses menyeluruh tersebut - intensitas framing dan frekuensi pemberitaan - dapat diartikan sebagai kesengajaan yang dilakukan oleh media sebagai aktor penting dalam sistem politik (Dorfman \& Herbert, 2007). Kesengajaan untuk memengaruhi pendapat publik bisa jadi adalah inisiatif institusi media, maupun inisiatif aktor di luar media yang memanfaatkan kekuatan media. Terlepas dari siapa inisiator yang berusaha memengaruhi pendapat publik melalui pemberitaan, 
framing berita adalah alat yang terbukti efektif untuk memengaruhi atau mengubah pendapat publik atas suatu isu.

Upaya media untuk memengaruhi kebijakan publik melalui pemberitaannya disebut sebagai advokasi media (Duru, 2016). Proses tersebut bersifat strategis dan deliberatif. Bukan hanya media yang melakukan advoksi kebijakan, namun pihak lain seperti partai politik, lembaga non pemerintah, perusahaan, dapat melakukannya, melalui media. Namun kunci dari proses advokasi tersebut adalah kemampuan media fokus pada suatu agenda tertentu, kemudian mem-framing-nya dalam berita-berita yang dia publikasikan (Tewksbury, Jones, Peske, Raymond, \& Vig, 2000). Oleh karena itu, framing berita atas isu tertentu yang bersifat advokatif disebut sebagai advocates framing atau framing advokasi.

Media membentuk framing advokasi kebijakan dengan strategi tertentu. Framing advokasi dilakukan dengan mengkonstruksi pesan dengan kuat dan memiliki karakteristik tertentu yang dapat diidentifikasi. Advokasi kebijakan melalui berita media memerlukan pesan yang jelas dan terstruktur, yang disampaikan dengan bahasa-bahasa yang persuasif(Tewksbury et al., 2000). Konstruksi pesan tersebut bertujuan untuk mengarahkan persepsi masyarakat dan opinion leader supaya memiliki pendapat sesuai yang diharapkan oleh media. Framing advokasi di dalam narasi berita selalu memiliki sudut pandang yang spesifik (Dorfman, Wallack, \& Woodruff, 2005), argumentasi yang persuasif dan eksplanasi yang sempit (Tewksbury et al., 2000). Hal ini disebabkan oleh mekanisme proses perumusan kebijakan yang merupakan pertarungan ide dan nilai. Di tengah pertarungan ide dan nilai yang objektif tersebut, advokasi mencari jalannya. Beragam strategi advokasi dilakukan oleh pihak-pihak yang berkepentingan. Salah satu strateginya adalah melalui advokasi media, yang pada level teknis melakukan advokasi melalui framing berita.

Framing advokasi dianggap tidak sesuai dengan prinsipobjektivitas berita. Ketidaksesuaian tersebut akibat dari sifat framing advokasi yang secara aktif mencoba mengontrol bagaimana suatu isu atau figur dideskripsikan dan digambarkan di media (Aday, 2016). Framing advokasi sangat spesifik dan mengkonstruksi dengan teliti cara-cara menginterpretasikan isu. Salah satu strategi framing advokasi adalah dengan membatasi konteks permasalahan. Pembatasan konteks permasalahan inilah yang terdapat di dalam teks-teks berita Kedaulatan Rakyat, sebagaimana dijelaskan di atas. Selain itu, framing advokasi sangat persuasif, yang sering terbaca di dalam judul dan lead berita.

Judul merupakan bagian dari berita yang paling mendapat perhatian pembaca. Berita yang bagus adalah berita yang memuat koherensi antara judul, lead dan isi berita. Selain sebagai penarik minat pembaca, judul seharusnya merepresentasikan isi berita sehingga suatu berita yang berkualitas tidak seharusnya hanya menampilkan judul yang menarik saja namun juga relevan dengan isinya. Framing berita memanfaatan judul sebagai salah satu "alat" paling kuat karena seringkali pembaca hanya membaca judul berita saja tanpa melanjutkan ke bagian isinya (De Vreese, 2005).

Dalam framing berita yang advokatif, judul memegang peran strategis (Tewksbury et al., 2000). Judul menggunakan kalimat-kalimat yang persuasif bahkan imperatif. Judul yang persuasif adalah judul yang menggunakan kalimat mengajak dan mengarahkan pembaca. Sementara, judul yang imperatif menggunakan kalimat-kalimat bernada memerintah atau menginstruksi. Berita-berita yang menjadi obyek penelitian ini memiliki judul-judul yang menggunakan kalimat imperatif. Judul-judul berita tersebut memuat kalimat-kalimat persuasif cenderung imperatif. Kalimat seperti "kuliah tatap muka harus dibuka", "hidupkan pariwisata dan pendidikan", dan "kampus diharap segera lakukan perkuliahan" merupakan judul yang bernada persuasif, bahkan imperatif. Meskipun tidak semua judul menggunakan 
kalimat perintah yang eksplisit, namun kesan yang ditimbulkan adalah kampus harus segera melaksanakan kuliah tatap muka untuk membantu membangkitkan perekonomian Yogyakarta. Selain itu, sebagian besar judul-judul tersebut tidak memuat subjek dan objek kalimat yang jelas sehingga membuka celah interpretasi yang luas.

Selain terdapat di dalam judul, bahasa yang persuasif juga ditemukan di dalam lead berita. Lead adalah paragraf pertama dalam narasi berita yang menjembatani judul dengan isi berita. Berita dengan struktur penulisan piramida terbalik biasanya memuat informasi $5 \mathrm{~W}$ (what, when, where, who, why) di dalam lead dan menjabarkan informasi penjelas di paragrafparagraf selanjutnya.

Lead adalah bagian dari berita yang paling kuat kedua untuk dijadikan alat framing advokasi (Tewksbury et al., 2000). Lead merupakan paragraf awal dimana informasi pokok disampaikan. Di samping itu, lead merupakan paragraf paling penting yang secara psikologis sangat mampu memengaruhi perspektif pembaca setelah judul berita. Narasi ekonomi menjadi gagasan pokok dari semua lead berita yang menjadi obyek penelitian ini, sesuai penjelasan di dalam sub bab sebelumnya. Hanya dua lead dalam dua berita terakhir yang memuat narasi tentang pentingnya protokol kesehatan dan fungsi gugus tugas kampus untuk mencegah penularan Covid-19 ketika perkuliahan tatap muka sudah diterapkan. Hal ini dapat diinterpretasikan sebagai adanya upaya Kedaulatan Rakyat untuk mem-framing isu bahwa perkuliahan daring menyebabkan perlambatan ekonomi Yogyakarta sehingga kampus-kampus harus segera menerapkan kuliah tatap muka kembali.

\section{SIMPULAN}

Pandemi Covid-19 menimbulkan dampak signifikan di banyak sektor termasuk sektor pendidikan tinggi. Perekonomian Daerah Istimewa Yogyakarta (DIY) yang mengandalkan pendapatan daerah dari wisatawan dan mahasiswa otomatis terimbas langsung. Wacana penerapan kembali perkuliahan tatap muka pun mengemuka di pemberitaan media-media lokal, termasuk Kedaulatan Rakyat. Melalui analisis framing, di dalam penelitian ini didapatkan hasil bahwa Kedaulatan Rakyat membentuk framing bahwa perkuliahan daring menjadi penyebab kontraksi ekonomi DIY dan kampus-kampus di DIY harus ikut memulihkan perekonomian dengan membuka kembali perkuliahan tatap muka. Framing tersebut juga memuat pesan advokasi yang kuat supaya para pimpinan Perguruan Tinggi di DIY segera membuka kembali perkuliahan luring dengan difasilitasi oleh Pemerintah Provinsi DIY. Namun demikian, pihak kampus juga harus bertanggung jawab atas penegakan disiplin protokol kesehatan di lingkungan kampusnya.

Artikel ini tentu memiliki keterbatasan. Penelitian yang dilakukan baru sampai pada tahap analisis pemberitaan Kedaulatan Rakyat terkait wacana perkuliahan luring di masa normal baru. Masih terdapat persoalan lain yang belum terjawab di dalam penelitian ini seperti misalnya mengapa Kedaulatan Rakyat sangat mengadvokasi pembukaan perkuliahan tatap muka dan apakah terdapat kepentingan ekonomi-politik di balik advokasi media tersebut. Persoalanpersoalan tersebut dapat digunakan sebagai dasar untuk penelitian-penelitian selanjutnya.

\section{DAFTAR PUSTAKA}

Aday, S. (2016). The Framesetting Effects of News: An Experimental Test of Advocacy versus Objectivist Frames. Journalism \& Mass Communication Quarterly, 83(4), 767-784. https://doi.org/10.1177/107769900608300403

Crow, D. A., \& Lawlor, A. (2016). Media in the Policy Process: Using Framing and Narratives to Understand Policy Influences. Review of Policy Research, 33(5), 472-491. https://doi. 
206 | Kajian Jurnalisme

Volume 04 Nomor 02 Tahun 2021

DOI: $10.24198 / \mathrm{jkj} . \mathrm{v} 4 \mathrm{i} 2.31300$

org/10.1111/ropr.12187

De Vreese, C. H. (2005). News framing: Theory and typology. Information Design Journal, 13(1), 51-62. https://doi.org/10.1075/idjdd.13.1.06vre

Dirikx, A., \& Gelders, D. (2010). To frame is to explain:A deductive frame-analysis of Dutch and French climate change coverage during the annual UN conferences of the parties. Public Understanding of Science, 19(6), 732-742. https://doi.org/10.1177/0963662509352044

Dorfman, L., \& Herbert, S. (2007). Shaping Public Debate with Framing and Messages. California: The California Endowment.

Dorfman, L., Wallack, L., \& Woodruff, K. (2005). More than a message: Framing public health advocacy to change corporate practices. Health Education and Behavior, 32(3), 320 336. https://doi.org/10.1177/1090198105275046

Dry, S., \& Leach, M. (2010). Epidemics: Science, Governance and Social Justice (1st ed.). London: Routledge. https://doi.org/10.4324/9781849776424

Duru, A. V. (2016). Framing the Ebola Outbreak: Systemic Influences on News Coverage. Louisiana State University.

Entman, R. M. (1993). Framing: Toward Clarification of a Fractured Paradigm. Journal of Communication, 43(4), 51-58. https://doi.org/10.1111/j.1460-2466.1993.tb01304.x

Entman, R. M. (2007). Framing bias: Media in the distribution of power. Journal of Communication, 57(1), 163-173. https://doi.org/10.1111/j.1460-2466.2006.00336.x

Heru. (2008, November 25). Mahasiswa Penyumbang Terbesar Pendapatan Yogyakarta. Tempo. Co. Diakses dari https://nasional.tempo.co/read/148026/mahasiswa-penyumbangterbesar-pendapatan-yogyakarta/full\&view $=$ ok

Ini Tiga Kebijakan Untuk Perguruan Tinggi Dalam Era New Normal. (2020, June 22). Batampos.Co.Id. Diakses dari https://batampos.co.id/2020/06/22/ini-tiga-kebijakanuntuk-perguruan-tinggi-dalam-era-new-normal/

Mejia, C. R., Ticona, D., Rodriguez-Alarcon, J. F., Campos-Urbina, A. M., Catay-Medina, J. B., Porta-Quinto, T., ... Tovani-Palone, M. R. (2020). The media and their informative role in the face of the coronavirus disease 2019 (COVID-19): Validation of fear perception and magnitude of the issue (MED-COVID-19). Electronic Journal of General Medicine, 17(6). https://doi.org/10.29333/ejgm/7946

Michael, D. F. (2020). Analisis Framing terhadap Berita Penanganan Covid-19 di Indonesia dalam okezone.com dan tribunnews.com. Universitas Pelita Harapan. Diakses dari http:// repository.uph.edu/id/eprint/9796

Mintarsih, S. S., Kodrat, D., \& Emiliasari, R. N. (2020). Tempo'S Perspective on the Representation of Government in Dealing With Covid-19 Cases. CALL: Critical Analysis on Language and Literature, 2(2), 125-137. https://doi.org/10.15575/call.v2i2.9403

Moy, P., Tewksbury, D., \& Rinke, E. M. (2016). Agenda-Setting, Priming, and Framing. In The International Encyclopedia of Communication Theory and Philosophy (pp. 1-13). https://doi.org/10.1002/9781118766804.wbiect266

Pieri, E. (2019). Media Framing and the Threat of Global Pandemics: The Ebola Crisis in UK Media and Policy Response. Sociological Research Online, 24(1), 73-92. https://doi. org/10.1177/1360780418811966

Putra, R. (2020, June 4). Skenario "New Normal” Perguruan Tinggi. Detiknews. Diakses dari https://news.detik.com/kolom/d-5039862/skenario-new-normal-perguruan-tinggi

Soroka, S. (2014). Negativity in Democratic Politics: Causes and Consequences. London: Cambridge University Press.

Syaifulloh, M., \& Idhom, A. M. (2015, April 7). Koran Kedaulatan Rakyat Diadukan ke Dewan 
Volume 04 Nomor 02 Tahun 2021

DOI: $10.24198 / j k j . v 4 i 2.31300$

Pers. Tempo.Co. Diakses dari https://nasional.tempo.co/read/655851/koran-kedaulatanrakyatdiadukan-ke-dewan-pers/full\&view $=$ ok

Tewksbury, D., Jones, J., Peske, M. W., Raymond, A., \& Vig, W. (2000). The interaction of news and advocate frames: Manipulating audience perceptions of a local public policy issue. Journalism and Mass Communication Quaterly, 77(4), 804-829. https://doi. org/10.1177/107769900007700406

Wibhisono, I. G. L. A. K. (2020). Framing Analysis of the Kompas' COVID-19 Coverage: January 2020 Edition. Jurnal ASPIKOM, 5(2), 219. https://doi.org/10.24329/aspikom. v5i2.717 